Steven Zarit is Professor and Head, Department of Human Development and Family Studies, Pennsylvania State University, University Park, Penn.

Competing interests: None declared.

\section{References}

1. Grunfeld E, Coyle D, Whelan T, Clinch J, Reyno L, Earle CC, et al. Family caregiver burden: results of a longitudinal study of breast cancer patients and their principal caregivers. CMA7 2004;170(12):1795-801.

2. Friss LR, Whitlatch CJ. Who's taking care? A statewide study of family caregivers. Am 7 Alzheimers Care Related Dis Res 1991;6:16-26.

3. Gallagher D, Rose J, Rivera P, Lovett S, Thompson LW. Prevalence of depression in family caregivers. Gerontologist 1989;29:449-56.

4. Pruchno RA, Resch NL. Aberrant behaviors and Alzheimer's disease: mental health effects on spouse caregivers. 7 Gerontol 1989;44(5): S177-S82.

5. Redinbaugh EM, MacCallum RC, Kiecolt-Glaser JK. Recurrent syndroma depression in caregivers. Psychol Aging 1995;10:358-68.

6. Schulz R, O'Brien AT, Bookwala J, Fleissner K. Psychiatric and physical morbidity effects of dementia caregiving: prevalence, correlates, and causes.
Gerontologist 1995;35:771-91.

7. Whitlatch CJ, Feinberg LF, Sebesta DS. Depression and health in family caregivers: adaptation over time. F Aging Health 1997;9(2):222-43.

8. Schulz R, Beach SR. Caregiving as a risk factor for mortality: the Caregiver Health Effects Study. 7AMA 1999;282:2215-9.

9. Haley WE, LaMonde LA, Han B, Burton AM, Schonwetter R. Predictors of depression and life satisfaction among spousal caregivers in hospice: application of a stress process model. 7 Palliat Med 2003;6:215-24.

10. Rabow MW, Hauser JM, Adams J. Supporting family caregivers at the end of life: "They don't know what they don't know." 7AMA 2004;291:483-91.

11. Sundström G, Johansson L, Hassing LB. The shifting balance of long-term care in Sweden. Gerontologist 2002;42:350-5.

12. Haley WE. The costs of family caregiving: implications for geriatric oncology. Crit Rev Oncol Hematol 2003;48(2):151-8.

Correspondence to: Steven Zarit, Department of Human

Development and Family Studies, 211 Henderson Building

South, Pennsylvania State University, University Park, PA 16802-

6505, USA; fax 814 863-7963; z67@psu.edu

\title{
Charging the patient to save the system? Like bailing water with a sieve
}

\section{Stephen Birch}

$\mathrm{H}$ ow can you tell the age of a Canadian? By the number of times they have heard Canadian politicians claim that publicly funded health care, free at the point of delivery, is not sustainable and that the survival of the health care system is dependent on the introduction of "patient participation" in meeting the costs of health care. In an age of evidence-based health policy, these claims stand out as a beacon of political hypocrisy and intellectual dishonesty, disregarding both the theoretical reasons and empirical evidence that support first-dollar coverage of health care as a key determinant of the efficient use of health care resources. ${ }^{1-6}$

On what basis can it be argued that charging patients for health care will save the system? Will it generate muchneeded additional resources to support the health care needs of an aging population? Will it reduce inefficiency by deterring people from visiting physicians unnecessarily? Will it free up much-needed resources to serve those in need, fund other public programs or reduce taxes? Finally, how will the health care system be configured under a regime of patient fees?

Suppose the next federal government were to amend the Canada Health Act to provide provincial administrations with the power to charge patients for insured services without loss of federal transfers. Based on health policies for access to many noninsured services in most provinces, provisions would be made so that certain groups would be exempt from the charges. Families on welfare, elderly people and, possibly, children might expect that they are protected from these charges because their ability to pay is compromised by their place in society. For example, according to Statistics Canada data for 2003, of Canada's 31.5 million residents, over 11 million are either children ( $\leq 19$ years) or elderly ( $\geq 65$ years) and another 3 million are unemployed (see www.statcan.ca /english/Pgdb/demo10a.htm and www.statcan.ca/english /Pgdb/labor07a.htm). Even without considering the working poor, almost half of the population would probably escape charges. Moreover, of the more than 7 million bed-days in acute care hospitals in Ontario, less than one third were occupied by adults under the age of 60 in $2002 . .^{7}$ In other words, only a relatively small proportion of all contacts would qualify for a charge. So, if we look on patient charges as a type of health-user tax, the tax base immediately shrinks. To raise any particular revenue target from patient charges, the level of charge must be substantial for those users who do not qualify for exemption. Hence, sustainable revenue streams from user charges will depend on a stream of chronically sick nonpoor adults. But the chronically sick are at a higher risk for unemployment and poverty, which means that they are likely to become exempt from charges. In addition, new administrative procedures would need to be set up to determine eligibility for exemption status and to collect fees. In the absence of expanding the number of administrators in health care, an increasing proportion of physi- 
cian time would have to be diverted from patient care to health care fee collection.

Even if user charges do not offer substantial revenue streams, surely they will deter people from the trivial and unnecessary use of scarce health care resources. Well, why should they? Initial visits to a physician represent only a small proportion of all physician contacts. The need for ongoing care is determined by the physician in response to the patient expressing some form of health problem. It may be that there is no health care need associated with that problem, but this must be determined by a physician. On what basis are patients supposed to know what is necessary and what is frivolous? Evidence from a major randomized control trial of patient charges showed that the proportions of inappropriate antibiotic use, hospital admissions and lengths of stay were the same with and without user fees. ${ }^{8-10}$

Although this should be sufficient evidence to convince even the "one-eyed" politician or policy-maker, it is also important to consider the nature of any inappropriate use of health care. Evans and colleagues ${ }^{4}$ estimated that less than $10 \%$ of expenditures under Canada's medicare program were patient-initiated (i.e., the initial visit to the physician), with the rest representing services requested or recommended by the physician. So, basing incentives for efficiency on a policy of patient charges is like using a sieve to bail water from a sinking ship. If unwarranted services are being provided, it would seem more appropriate to aim incentives to deter abuse at those responsible for requesting or delivering the service. That would indicate a shift from item-of-service to population-based forms of provider payment, where the provider, as opposed to the patient or taxpayer, incurs the costs of services from a predetermined budget.

Suppose, however, that the proponents of patient charges are right and that fees deter the healthy from using health care services, leaving only the sick to make demands on the system. What does this mean? Those not needing health care, and hence free of all the adverse consequences of sickness, avoid paying the patient charge, leaving only the sick to pay. The success of a patient charge policy is therefore dependent on only the sick paying the "tax" that a patient charge represents. But if only the sick pay for care, what is the point of having a public health care system?

Does this mean that health is something that cannot be subjected to incentive structures used in so many other areas of society? No, it simply means that we need a clear understanding of what determines individual behaviour with respect to the production of health, illness and recovery in populations. Investing in health at the individual and community levels will depend on both the capacity to invest, in terms of access to resources required to promote and protect health, and the rewards to investment, in terms of the value of health improvements produced. ${ }^{11}$ The value of improving the prospects of a healthy life in older years may depend on the quality of circumstances one expects to enjoy during those years. Amendments to pension legislation that prevent major corporations from introducing reductions in pension rights of their employees (and retirees) may have a far greater effect on encouraging people to adopt healthier lifestyles than will taxing them if they don't.

Stephen Birch is with the Centre for Health Economics and Policy Analysis, McMaster University, Hamilton, Ont.

Competing interests: None declared.

\section{References}

1. Barer M, Evans R, Stoddart GC. Controlling health care costs by direct charges to patients: snare or delusion? Occasional Paper 10. Toronto: Economic Council; 1979.

2. Birch S. Patient charges in the NHS and the privatisation of primary care. 7 Soc Policy 1986;15:163-84.

3. Beck RG, Horne J. Utilization of publicly insured health services in Saskatchewan before, during and after copayment. Med Care 1980;18:787-806.

4. Evans R, Barer M, Stoddart G. The truth about user fees. Policy Options 1993;14:4-9.

5. Evans R, Barer M, Stoddart G. Charging Peter to pay Paul: accounting for the financial effects of service charges. Toronto: Premier's Council on Health, Well-being and Social Justice; 1994.

6. Evans R, Barer M, Stoddart G. User fees for health care: why a bad idea keeps coming back (or what's health got to do with it?). Can F Aging 1995;14:360-90.

7. Canadian Institute for Health Information. Discharge abstract database. Ottawa: The Institute; 2003.

8. Lohr K, Brook R, Kamberg C, Goldberg G, Leibowitz A, Keesey J, et al. Use of medical care in the Rand Health Insurance Experiment. Diagnosis- and service-specific analyses in a randomized controlled trial. Med Care 1986;24(Suppl 9):S1-87.

9. Siu AL, Sonnenberg FA, Manning WG, Goldberg GA, Bloomfield ES, Newhouse JP, et al. Inappropriate use of hospitals in a randomized trial of health insurance plans. N Engl F Med 1986;315(20):1259-66.

10. Foxman B, Valdez RB, Lohr KN, Goldberg GA, Newhouse JP, Brook RH, et al. The effect of cost sharing on the use of antibiotics in ambulatory care: results from a population-based randomized controlled trial. 7 Chronic Dis 1987;40(5):429-37.

11. Birch S, Stoddart G. Incentives to be healthy: an economic model of healthrelated behaviour. In: Lopez-Casasnovas G, editor. Incentives in bealth systems. Heidelberg: Springer-Verlag; 1991:169-87.

Correspondence to: Stephen Birch, McMaster University, Rm. HSC 3H30, 1200 Main St. W, Hamilton ON L8N 3Z5; fax 905 546-5211; e-mail birch@mcmaster.ca 